\title{
Seasonal variation in the nature of DOM in a river and drinking water reservoir of a closed catchment ${ }^{\text {th }}$
}

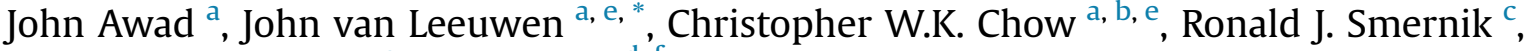 \\ Sharolyn J. Anderson a , Jim W. Cox ${ }^{\mathrm{d}, \mathrm{f}}$ \\ a School of Natural and Built Environments, University of South Australia, South Australia, 5095, Australia \\ ${ }^{\mathrm{b}}$ Australian Water Quality Centre, SA Water Corporation, 250 Victoria Square, Adelaide, South Australia, 5000, Australia \\ ' School of Agriculture, Food \& Wine and Waite Research Institute, The University of Adelaide, Urrbrae, South Australia, 5064, Australia \\ d School of Biological Sciences, The University of Adelaide, North Terrace, South Australia, 5005, Australia \\ e SKLEAC, Research Centre for Eco-environmental Sciences, Chinese Academy of Sciences, P.O. Box 2871, Beijing, 100085, China \\ ${ }^{\mathrm{f}}$ South Australian Research and Development Institute, Urrbrae, South Australia, 5064, Australia
}

\section{A R T I C L E I N F O}

\section{Article history:}

Received 3 August 2016

Received in revised form

12 October 2016

Accepted 18 October 2016

Available online 4 November 2016

\section{Keywords:}

Surface waters

Seasonal variation

Treatability of organic

THMFP

\begin{abstract}
A B S T R A C T
Dissolved organic matter (DOM) in surface waters used for drinking purposes can vary markedly in character depending on its source within catchments and the timing and intensity of rainfall events. Here we report the findings of a study on the character and concentration of DOM in waters collected during different seasons from Myponga River and Reservoir, South Australia. The character of DOM was assessed in terms of its treatability by enhanced coagulation and potential for disinfection by-product i.e. trihalomethane (THM) formation. During the wet seasons (winter and spring), water samples from the river had higher DOC concentrations ( $\overline{\mathrm{X}}: 21 \mathrm{mg} / \mathrm{L}$ ) and DOM of higher average molecular weight (AMW: $1526 \mathrm{Da}$ ) than waters collected during the dry seasons (summer and autumn: DOC: $13 \mathrm{mg} / \mathrm{L}$; AMW: $1385 \mathrm{Da}$ ). Even though these features led to an increase in the percentage removal of organics by coagulation with alum (64\% for wet compared with $53 \%$ for dry season samples) and a lower alum dose rate (10 versus $15 \mathrm{mg}$ alum/mg DOC removal), there was a higher THM formation potential (THMFP) from wet season waters (treated waters: $217 \mu \mathrm{g} / \mathrm{L}$ vs $172 \mu \mathrm{g} / \mathrm{L}$ ). For reservoir waters, samples collected during the wet seasons had an average DOC concentration ( $\bar{X}: 15 \mathrm{mg} / \mathrm{L})$, percentage removal of organics by alum (54\%), alum dose rates (13 mg/mg DOC) and THMFP (treated waters: $207 \mu \mathrm{g} / \mathrm{L}$ ) that were similar to samples collected during the dry seasons (mean DOC: $15 \mathrm{mg} / \mathrm{L}$; removal of organics: $52 \%$; alum dose rate: $13 \mathrm{mg} / \mathrm{mg}$ DOC; THMFP: $212 \mu \mathrm{g} / \mathrm{L}$ for treated waters). These results show that DOM present in river waters and treatability by alum are highly impacted by seasonal environmental variations. However these in reservoir waters exhibit less seasonal variability. Storage of large volumes of water in the reservoir enables mixing of influent waters and stabilization of water quality.
\end{abstract}

Crown Copyright $\odot 2016$ Published by Elsevier Ltd. All rights reserved.

\section{Introduction}

The concentration of dissolved organic matter (DOM) presented in surface waters (e.g., streams and reservoirs) is influenced by the

\footnotetext{
ش This paper has been recommended for acceptance by Dr. Harmon Sarah Michele.

* Corresponding author. Natural \& Built Environments Research Centre,

University of South Australia, H3-26 Mawson Lakes Campus, Adelaide, SA, 5095, Australia.

E-mail address: John.vanleeuwen@unisa.edu.au (J. van Leeuwen).
}

climate and season changes (Chen et al., 2015; Mattsson et al., 2009). It has been reported that during storm events, there is an increase in DOM concentration in stream water (Evans et al., 2005) and in reservoir water (Chen et al., 2015) and this is attributed to flushing of the upper organic soil horizons (Ritson et al., 2014). DOM concentrations (measured as dissolved organic carbon, DOC) within streams have been found to have a positive relation with stream discharge (Billett et al., 2006). Highest concentrations of DOC released into subsurface waters and lateral flows occur after the first major rainfall event in the break-of-season during late autumn/early winter, demonstrating the importance of fresh litter 
material in generating high amounts of soluble organic matter (Chow et al., 2011).

Storm events lead to an increase in the percentage of humic-like and aromatic organic compounds present in catchment runoff as reported by Carstea et al. (2009) and Stutter et al. (2012). Goslan et al. (2002) reported an increase in the percentage of the hydrophobic acid fraction in waters of a reservoir inlet (Albert, Yorkshire) during the winter season compared to other seasons. Chen et al. (2015) also reported that DOM present in reservoir waters (Bohyunsan Reservoir, South Korea) during the wet season has higher SUVA (specific UV absorbance) with lower apparent of small molecular weight (MW) fraction than during dry season. Increasing water temperatures can lead to an increase in microbial activity and consequently greater formation of hydrophilic compounds (Lumsdon et al., 2005). Further, with increasing UV irradiation during the dry season there is increase in the photo-degradation rates of coloured DOM (Zepp et al., 2007) mainly aromatic organic compounds. Aromatic compounds have been found to be susceptible to photo-oxidation (Ritson et al., 2014).

Natural organic matter (NOM) present in drinking water sourced from reservoir catchments may lead to health risks. These risks include formation of disinfection by-products (DBPs), including trihalomethanes (THMs), haloacetic acids, iodo-acids, halonitromethanes, nitrosamines, and dichloroacetamide that form when NOM reacts with chemical disinfectants (Chu et al., 2010; Richardson and Postigo, 2012). For chlorinated waters, THM levels have been found to be highest in concentration compared to other by products (King et al., 2000a). In comparison to other DBPs, THM have the highest skin permeability (Carter et al., 2015) and the toxicity of disinfected waters can be evaluated based on THM concentrations (Allard et al., 2015). THM levels have also been linked to several health effects such as elevated rates of bladder and brain cancers (Agency, 2012; King et al., 2000b; Richardson et al., 2007; Siddique et al., 2015; Villanueva et al., 2007), still-births and miscarriages (King et al., 2000a; Richardson, 2005). A recent study (Min and Min, 2016) has reported that blood THM levels (mainly brominated THM) were significantly linked with the total number of adults' cancer mortality in the United States.

The removal of organics that are the precursors of DBPs of health concern, is therefore of high importance. Coagulation and flocculation are the most widely used processes for removal of DOM from drinking water (Matilainen et al., 2010) even though it can only be partially removed. Enhanced coagulation refers to maximizing total or dissolved organic carbon (TOC or DOC) removal from drinking water by increasing the coagulant dose and controlling the coagulation pH level to the coagulation optimum (White et al., 1997). Optimum DOC removal can be defined as the point of diminishing returns in terms of chemical use, where an additional $10 \mathrm{mg} / \mathrm{L}$ of coagulant results in less than $0.15 \mathrm{mg} / \mathrm{L}$ DOC reduction (van Leeuwen et al., 2005). The treatability (or removal capacity) of organics present in drinking water by coagulation/flocculation is affected by a range of factors of the raw water quality including $\mathrm{pH}$, alkalinity and the character of the DOM (Chow et al., 1999, 2009).

Although many studies have shown that the presence of DOM in surface waters is influenced by a combination of biophysical properties of a catchment within the watershed and the timing and intensity of rainfall events, there is a paucity of studies on the effect of these characteristics on the quality of water for domestic consumption. Here we report the findings of a study on the changes in the character and concentrations of aquatic DOM during different seasons and rainfall events in an enclosed catchment's river and reservoir (Myponga, South Australia). The character of DOM was also assessed in context of potential treatability by coagulation/flocculation treatment and THM formation potential.

\section{Methodology}

\subsection{Study area}

This study was conducted in the Myponga reservoir-catchment $\left(35^{\circ} 18^{\prime}\right.$ to $35^{\circ} 25^{\prime} \mathrm{S}$ and $138^{\circ} 24^{\prime}$ to $138^{\circ} 33^{\prime} \mathrm{E}$ ) which is part of the Mount Lofty Ranges watershed, $50 \mathrm{~km}$ south of Adelaide, South Australia, Australia. Water samples were collected from the Myponga River and Myponga Reservoir between March 2014 and February 2015. Samples were transported to the laboratory at ambient temperature in $\sim 2 \mathrm{~h}$ and stored at $4{ }^{\circ} \mathrm{C}$ until analyzed. The rainfall pattern of Myponga, shown in Fig. 1a, is strongly seasonal with hot dry summers and cool wet winters.

\subsection{The concentration and character of DOM}

For determination of the concentration of DOM measured as DOC and UV absorbance, water samples were passed through $0.45 \mu \mathrm{m}$ pre-rinsed sterile cellulose membrane filters prior to analyses. DOC concentration was determined using a TOC analyser (Model 900, Sievers Instruments). UV-Visible light absorbances were measured using a spectro-photometer (UV-120, MIOSTECH Instruments) for wavelengths from $200 \mathrm{~nm}$ to $700 \mathrm{~nm}$, using a quartz cuvette of $1 \mathrm{~cm}$ path length. Color in Hazen Units (HU) was determined by absorbance at $456 \mathrm{~nm}$ using a $5 \mathrm{~cm}$ path length, glass cuvette and a platinum/cobalt standard ( $50 \mathrm{HU})$. Specific UV absorbance or SUVA (the ratio of absorbance at $254 \mathrm{~nm} / \mathrm{m}$ to the concentration of DOC), (Edzwald and Tobiason, 1999) and Specific color (SpCol, the ratio of color in HU to DOC concentration), (van Leeuwen et al., 2005) were determined.

Separation of organic compounds based on apparent molecular weight (MW) distributions was performed using HPSEC (A Waters 2690 Separation Module and Waters 996 photodiode array detector) with UV detection at $260 \mathrm{~nm}$ wavelength, as described by Chow et al. (2008). Column size and type, flow rate and other relevant information for the HPSEC-UV detection method have been previously reported (Chow et al., 2008). Water samples for HPSEC analysis were passed through $0.22 \mu \mathrm{m}$ sterile cellulose membrane filters prior to the analysis. The weight-averaged molecular weight $\left(\right.$ AMW $\left.=\sum n \times M W / \sum n\right)$ was calculated as described by Chow et al. (2008). HPSEC chromatograms were analyzed using a peak fitting technique (Peak Fit software, Version 4, Systat Software Inc.) to resolve overlapping peaks as reported by Aslam et al. (2013). Peaks detected by absorbance at UV260 nm had MWs of 58,300 (Peak 1), 8600 (Peak 2), 4450 (Peak 3), 2700 (Peak 4), 1750 (Peak 5), 1250 (Peak 6), 830 (Peak 7), 515 (Peak 8) and 390 (Peak 9) Da.

Apparent MW distributions of humic-like compounds were measured using HPSEC with fluorescence detection, as described by Aslam et al. (2013). Excitation and emission wavelengths (320ex/ $430 \mathrm{em}$ ) were used to investigate the MW distributions of humiclike compounds (Chen et al., 2003). HPSEC chromatograms were analyzed by a peak-fitting technique. Peak fitting of the chromatographs of humic-like compounds produced peaks with average MWs of 2345 Da (Peak 1), 1600 Da (Peak 2), 1175 Da (Peak 3), $810 \mathrm{Da}$ (Peak 4), $485 \mathrm{Da}$ (Peak 5) and $370 \mathrm{Da}$ (Peak 6).

\subsection{Enhanced coagulation and THM formation potential}

For testing of the treatability of the organics by alum, DOC concentrations of water samples, as collected from Myponga River and reservoir, were treated by coagulation/flocculation process at ambient temperature and $\mathrm{pH} 6 \pm 0.1$ (Chow et al., 2009) using aluminium sulfate (alum; $\left.\mathrm{Al}_{2}\left(\mathrm{SO}_{4}\right)_{3} \cdot 18 \mathrm{H}_{2} \mathrm{O}\right)$. An enhanced dose (ED) of alum was estimated by $\mathrm{mEnCo}^{\odot}$ model (van Leeuwen et al., 2005; van Leeuwen et al., 2009). The $\mathrm{mEnCo}^{\odot}$ model was 

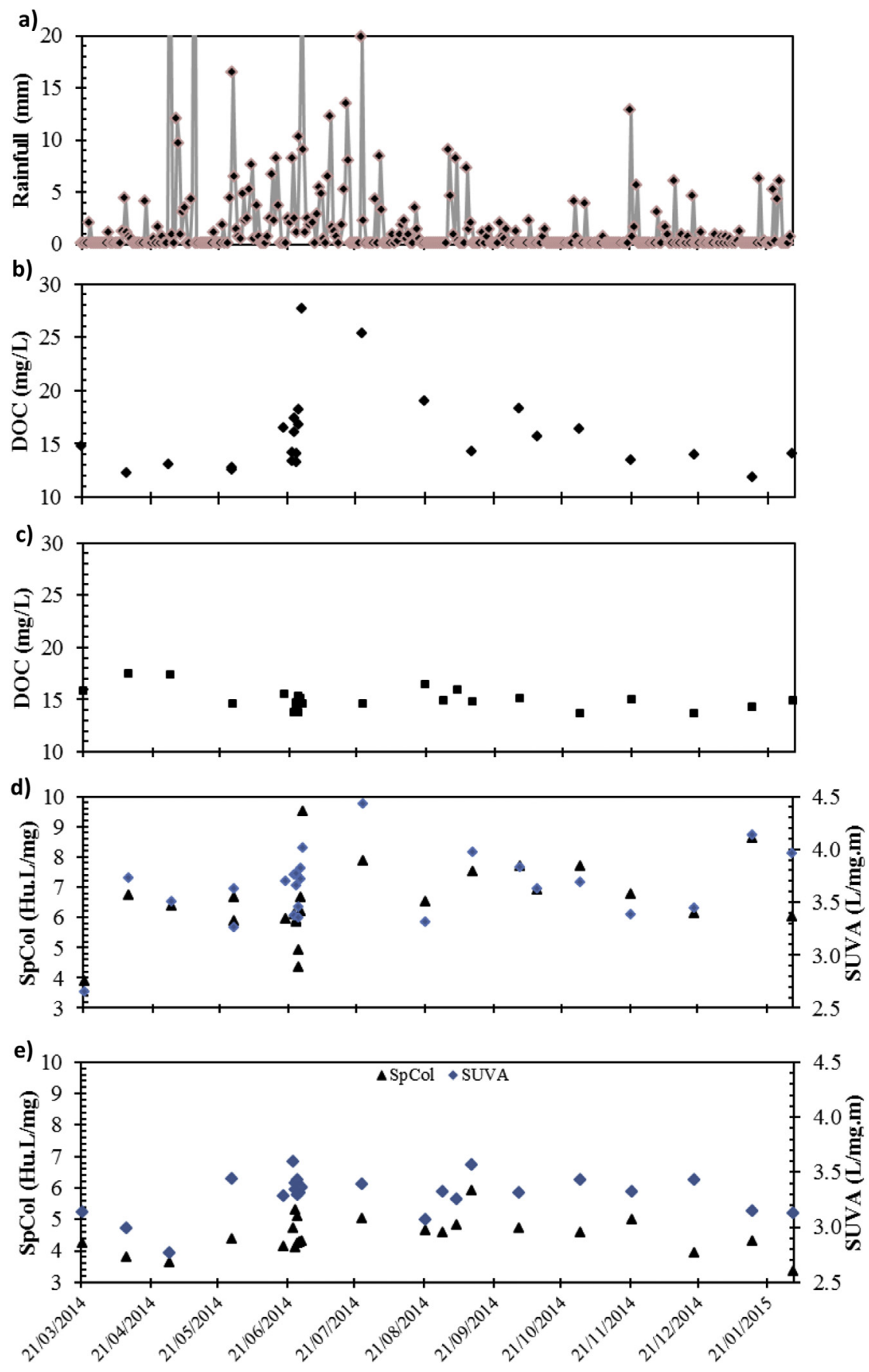

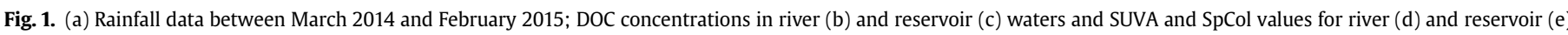
waters, respectively.

developed for raw waters such as rivers and reservoirs used for portable supply.

Total THMFP and formation of constituent THM compounds (four chloro/bromo compounds) were determined for treated waters by a headspace sampler (Perkin Elmer, TurboMatrix 110) and gas chromatograph with electron-capture detection (Perkin Elmer Clarus $^{\circledR} 500$ GC). THM compounds were formed after $20 \mathrm{mg} / \mathrm{L}$ chlorine addition under controlled laboratory conditions of $35^{\circ} \mathrm{C}$ and $\mathrm{pH}$ 7.4, and held for $4 \mathrm{~h}$ as reported by Fabris et al. (2008) and by $\mathrm{Ng}$ et al. (2013). Br concentration presented in raw waters was measured using Standard Method 4110 (Rice et al., 2012).

\subsection{DOM loading}

The DOC loading from reservoir input (Myponga River) into the reservoir and reservoir output (from the Myponga water treatment plant; WTP), were calculated using Beale's stratified ratio estimator (Beale, 1962; Ran et al., 2013), equations (1)-(3). According to Quilbé et al. (2006), this method is a good for estimating different pollutants when daily measurement of flow is recorded but only a few data of the concentrations of pollutants are available. 
$\mathrm{L}_{\mathrm{D}}=\mu_{\mathrm{Q}_{1}} \times \frac{\mu_{\mathrm{DOC}}}{\mu_{\mathrm{Q}_{2}}}\left[\frac{1+\frac{1}{n} \times \frac{\mathrm{S}_{\mathrm{Q}_{2} \mathrm{DOC}}}{\mu_{\mathrm{DOC}} \times \mu_{\mathrm{Q}_{2}}}}{1+\frac{1}{\mathrm{n}} \times \frac{\mathrm{S}_{\mathrm{Q}_{2}}^{2}}{\mu_{\mathrm{Q}_{2}}^{2}}}\right]$

$\mathrm{S}_{\mathrm{Q}_{2} \mathrm{DOC}}=\frac{1}{\mathrm{n}-1} \times \sum_{\mathrm{i}=1}^{\mathrm{n}} \mathrm{DOC}_{\mathrm{i}} \times \mathrm{Q}_{\mathrm{i}}-\left(\mathrm{n} \times \mu_{\mathrm{Q}_{2}} \times \mu_{\mathrm{DOC}}\right)$

$\mathrm{S}_{\mathrm{Q}_{2}}^{2}=\frac{1}{\mathrm{n}-1} \times \sum_{\mathrm{i}=1}^{\mathrm{n}} \mathrm{Q}_{\mathrm{i}}^{2}-\left(\mathrm{n} \times \mu_{\mathrm{Q}_{2}}^{2}\right)$

where: $L_{D}$, DOC loading (DOC concentration $x$ water flow, g/d); $\mu_{\mathrm{Q} 1}$, mean daily water flow $\left(\mathrm{m}^{3} / \mathrm{d}\right) ; \mu_{\mathrm{DOC}}$, mean DOC concentration $(\mathrm{g} /$ $\mathrm{m}^{3}$ ); $\mu_{\mathrm{Q} 2}$, mean daily water flow for the days on which DOC was measured $\left(\mathrm{m}^{3} / \mathrm{d}\right)$; $\mathrm{n}$, number of the days on which DOC was measured; $D O C_{i}$, individual DOC concentration $\left(\mathrm{g} / \mathrm{m}^{3}\right) ; \mathrm{Q}_{\mathrm{i}}$, individual daily water flow $\left(\mathrm{m}^{3} / \mathrm{d}\right)$; $\mathrm{S}_{\mathrm{Q} 2 \mathrm{DOC}}$, variance value of DOC loading for the days on which DOC was measured; $\mathrm{S}_{\mathrm{Q} 2}$, standard deviation of water flow for the days on which DOC was measured.

\section{Results and discussion}

\subsection{DOM concentration and character in raw waters}

Using equations (1)-(3), the total DOC transported by the Myponga River determined over the study period was 122.7 ton/y (annual average, $26.1 \mathrm{mg} / \mathrm{L}$ ) and the total loading in the reservoir output was 70.9 ton/y (annual average, $15.0 \mathrm{mg} / \mathrm{L}$ ). The concentrations of DOC in river waters showed seasonal variation with the highest values [mean value: $26.5 \mathrm{mg} / \mathrm{L}(1028 \mathrm{~kg} / \mathrm{d})$ ] occurring in the winter season (June-August 2014) followed by the spring season [September-November 2014; mean: $14.8 \mathrm{mg} / \mathrm{L}$ (84 kg/d)], autumn [March-May 2014; mean: $12.9 \mathrm{mg} / \mathrm{L}(62 \mathrm{~kg} / \mathrm{d})$ ] and summer [December 2014-February 2015; mean: $12.1 \mathrm{mg} / \mathrm{L}(18 \mathrm{~kg} / \mathrm{d})$ ], shown in Fig. 1b. This finding is similar to that reported by Evans et al. (2005) and Billett et al. (2006). Evans et al. (2005) reported an increase in DOM concentrations in stream waters during storm events and Billett et al. (2006) reported that DOC concentrations in streams have a positive relation with stream discharge.

In contrast, DOC concentrations in reservoir waters showed a different trend (Fig. 1c), with the mean organic concentration found to be similar between various seasons [mean: $16 \mathrm{mg} / \mathrm{L}(173 \mathrm{~kg} / \mathrm{d})$ for autumn, $15 \mathrm{mg} / \mathrm{L}$ (132 kg/d) for winter, $15 \mathrm{mg} / \mathrm{L}$ (210 kg/d) for spring, and $14 \mathrm{mg} / \mathrm{L}(261 \mathrm{~kg} / \mathrm{d})$ for summer]. These smaller variations are attributed to the high water holding capacity (time) of Myponga Reservoir (mean $4.6 \mathrm{y}$ ). The holding time, ratio of average holding capacity to the outflow rate (at WTP) of the Myponga Reservoir were calculated based on the average holding capacity of $85.5 \pm 5.4 \%$ of the maximum storage capacity $\left(22,902,833 \mathrm{~m}^{3}\right)$ and the outflow rate of $4,787,440 \mathrm{~m}^{3} / \mathrm{y}$.

UV-Vis spectroscopy was performed to characterize DOM, based on the presence of UV absorbing and chromophoric organic constituents, including aromatic groups as reported by Weishaar et al. (2003) and Korshin et al. (2009). SUVA and SpCol of DOM present in river and reservoir waters are shown in Fig. 1d and 1e respectively. These two parameters are used in the drinking water industry to characterize DOM as a means of assessing treatment needs in the supply of potable water.

For river waters, mean values of SUVA were $3.36 \pm 0.39 \mathrm{~L} /(\mathrm{mg}$ $\mathrm{m})$ in autumn, $3.70 \pm 0.30 \mathrm{~L} /(\mathrm{mg} \mathrm{m})$ in winter, $3.70 \pm 0.30 \mathrm{~L} /(\mathrm{mg} \mathrm{m})$ in spring and $3.85 \pm 0.29 \mathrm{~L} /(\mathrm{mg} \mathrm{m})$ in summer. This parameter was higher at the wet season compared with the end of the dry season,
Fig. 1d. The highest SUVA $[\sim 4.2 \mathrm{~L} /(\mathrm{mg} \mathrm{m})]$ occurred at the end of June and July while the lowest SUVA level $[\sim 2.65 \mathrm{~L} /(\mathrm{mg} \mathrm{m})]$ occurred in March for the period of investigation. SpCol levels showed the same trend with values higher for water samples collected at the start of the wet season $(\sim 9.5 \mathrm{HU} \mathrm{L} / \mathrm{mg})$ compared with the end of the dry season $(\sim 3.9 \mathrm{HU} \mathrm{L} / \mathrm{mg})$, Fig. $1 \mathrm{~d}$. Storm events led to an increase in the percentage of humic-like and aromatic organics compounds in stream/river waters as reported by Carstea et al. (2009) and Stutter et al. (2012).

Mean SUVA levels in the reservoir waters (Fig. 1e) were slightly lower in the dry season $[3.15 \pm 0.22 \mathrm{~L} /(\mathrm{mg} \mathrm{m})]$ compared with the wet season $[3.36 \pm 0.11 \mathrm{~L} /(\mathrm{mg} \mathrm{m})]$. SpCol levels showed the same trend with values lower for waters collected in autumn and summer than other seasons [means: $4.01 \pm 0.32 \mathrm{HU} \mathrm{L} / \mathrm{mg}$ for autumn, $4.56 \pm 0.39 \mathrm{HU} \mathrm{L} / \mathrm{mg}$ for winter, $5.0 \pm 0.47 \mathrm{HU} \mathrm{L} / \mathrm{mg}$ for spring and $3.87 \pm 0.40 \mathrm{HU} \mathrm{L} / \mathrm{mg}$ for summer months], Fig. 1e. Warmer water temperatures lead to increase in microbial activity and consequently greater formation of hydrophilic compounds (Lumsdon et al., 2005). Further, with increasing UV irradiation levels during the dry season there is increase in the photo-degradation rates of coloured DOM (Zepp et al., 2007) mainly aromatic organic compounds (Ritson et al., 2014).

Organic constituents of the river and reservoir waters were analyzed by HPSEC with UV detection. The mean AMW of organics of river waters collected in the wet seasons (winter-spring: $1526 \pm 125 \mathrm{Da}$ ) was higher than of the dry seasons (summerautumn: $1385 \pm 129 \mathrm{Da}$ ), Fig. 2a. Similar to SUVA and SpCol, the highest AMW value ( 1721 Da) was found in waters collected between the end of June and July while the lowest AMW value ( $1239 \mathrm{Da})$ was found in water collected in March. For reservoir waters, the mean AMW values were similar for the wet $(1332 \pm 32.7 \mathrm{Da})$ and dry $(1290 \pm 46 \mathrm{Da})$ seasons.

In order to resolve peaks from HPSEC chromatographs, a peak fitting technique was applied and the relative abundance of each peak area determined, shown in Supplementary data, Fig. S1. For river waters, relative abundances of HMW peaks (P1:P4: MW $>2 \mathrm{KDa}$ ) were lower in flow collected during the dry season (summer-winter: $10 \pm 4.2 \%$ ) than in the wet season (winter-spring: $17 \pm 6.2 \%$, Fig. S1. In contrast, the relative abundances of LMW peaks (P7:P9: MW < $1.0 \mathrm{KDa}$ ) were similar between wet and dry seasons $(20 \pm 1.4 \%$ during wet seasons and $22 \pm 2.5 \%$ during dry seasons). For reservoir waters, the abundances of organics of HMW and LMW (peaks) were similar between the wet and dry seasons (wet seasons: $8 \pm 0.8 \%$ for P1:P4 and $24 \pm 1.4 \%$ for P7:P9; dry seasons: $8 \pm 1.6 \%$ for $\mathrm{P} 1: \mathrm{P} 4$ and $23 \pm 1.1 \%$ for $\mathrm{P} 7: \mathrm{P} 9)$.

Organic constituents of the river and reservoir waters were also analyzed by HPSEC with fluorescence detection to estimate the molecular weight distributions of humic-like compounds. The AMW of organics of river waters collected in the wet seasons (winter-spring: $1008 \pm 6.7 \mathrm{Da}$ ) were higher than of the dry seasons (summer-autumn: $923 \pm 21.3 \mathrm{Da}$ ), Fig. 2b. Mean AWM-humic level in the reservoir waters were slightly higher in the wet season $[971 \pm 19 \mathrm{Da}]$ compared with the dry season [938 $\pm 29 \mathrm{Da}]$. For the reservoir waters, the lowest AWM-humic level (882 Da) was found in water samples collected in the summer season.

Peak fitting was performed and the relative abundance of each peak area determined. For river waters, the relative combined abundances of peaks P4:P6 ( MW $<1 \mathrm{KDa}$ ) were greater in flows collected in the dry seasons $(40 \pm 2.3 \%)$ than in the wet seasons (32 $\pm 1.8 \%$ ), Supplementary data (Fig. S2). The relative abundances of peaks P2:P3 ( $1 \mathrm{KDa}<\mathrm{MW}<1.3 \mathrm{KDa}$ ) were lower in flows collected in the dry seasons $(60 \pm 2.3 \%)$ than in the wet seasons $(66 \pm 3.3 \%)$. Peak 1 (2345 Da) did not appear in flows collected in the dry seasons while in the wet seasons, this peak was detected with a mean relative abundance of $2 \pm 1.6 \%$ (Fig. S2). 

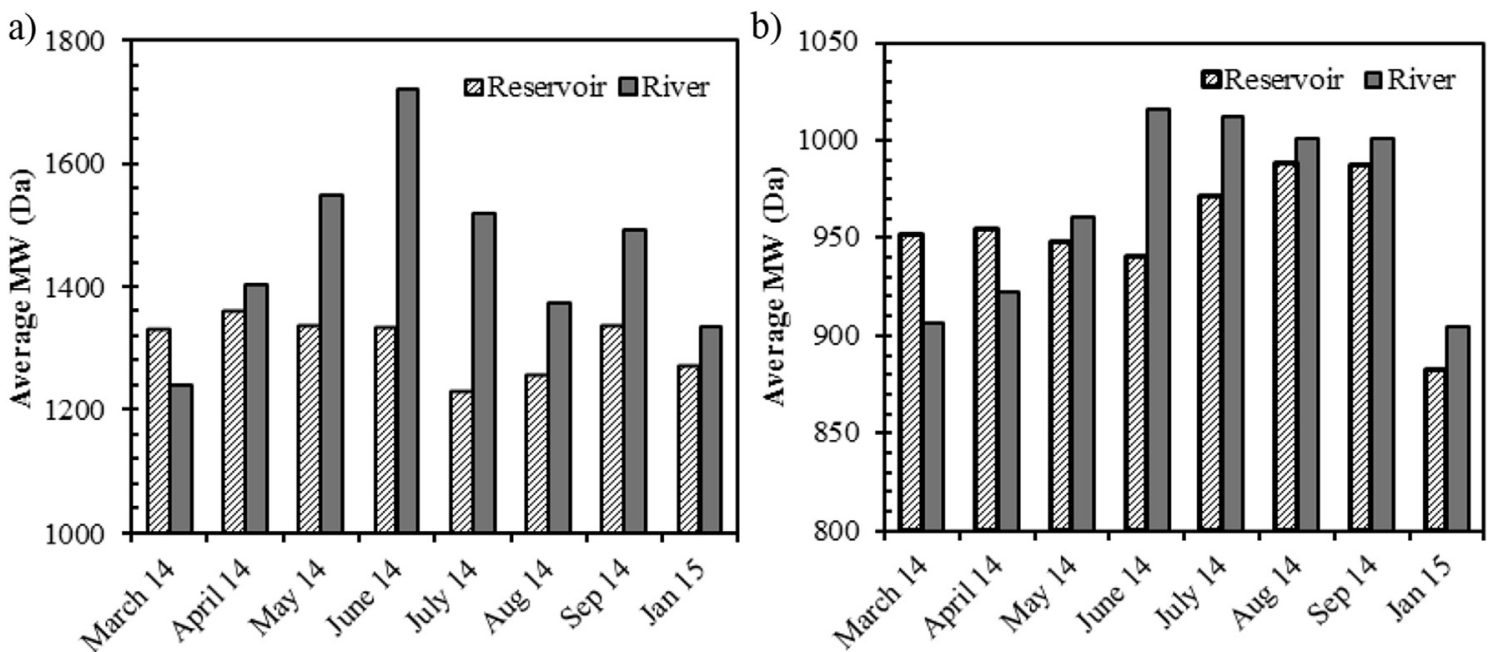

Fig. 2. Average AMW of UV absorbance compounds (a) and of humic-like compounds (b) of river and reservoir waters.

For reservoir waters, the relative abundances of peaks $\mathrm{P} 4: \mathrm{P} 6$ were similar in flows collected in the dry seasons $(39 \pm 2.2 \%)$ compared with the wet seasons $(36 \pm 1.8 \%)$. Also, the \% of peaks P2:P3 and P1 were similar in waters collected in the dry seasons (59 $\pm 2.4 \%$ for $\mathrm{P} 2: \mathrm{P} 3$ and $1 \pm 0.9 \%$ for $\mathrm{P} 1$ ) to those of the wet seasons ( 62 $\pm 2.3 \%$ for $\mathrm{P} 2: \mathrm{P} 3$ and $2 \pm 1.9 \%$ for P1). The highest abundances of LMW compounds were in flows in January (Fig. S2).

\subsection{Alum dose and DOC removal}

Percentage removals of DOC from water by alum treatment at ED (\%DOC Rem ) under standardized conditions and alum dose rates (mg alum per mg DOC removed) applied at ED (Al/DOC), are presented in Fig. 3. Average percentage removals of DOC from river waters $(58 \pm 10 \%)$ were slightly higher than reservoir water (53 $\pm 3 \%$ ), while the $\mathrm{Al} / \mathrm{DOC}$ for the river waters ( $13 \pm 3 \mathrm{mg} / \mathrm{mg}$ DOC removed) was similar to the reservoir waters $(13 \pm 1 \mathrm{mg} / \mathrm{mg}$ DOC removed), as shown in Fig. 3b.

For river waters, $\% \mathrm{DOC}_{\mathrm{Rem}}$ by alum treatment were greater for water samples collected during wet seasons $(64 \pm 5 \%)$ than waters collected during the dry seasons $(53 \pm 10 \%)$. The $\mathrm{Al} / \mathrm{DOC}$ data showed a consistent trend with values lower in waters collected during wet seasons (10 $\pm 2 \mathrm{mg} / \mathrm{mg}$ DOC removed) than waters collected during the dry seasons $(15 \pm 3 \mathrm{mg} / \mathrm{mg}$ DOC removed). Coefficient of variation values for these waters collected during the wet and dry seasons were calculated and these are $9.4 \%$ and $20 \%$ for $\% \mathrm{DOC}_{\text {Rem }}$ and $\mathrm{Al} / \mathrm{DOC}$ respectively. This shows that organic compounds present in surface waters of the wet seasons were more amenable to removal by coagulation than the waters collected during dry seasons, and this corresponds with the DOM characters. Organics collected during wet seasons had high relative abundances of high MW humic and aromatic compounds compared
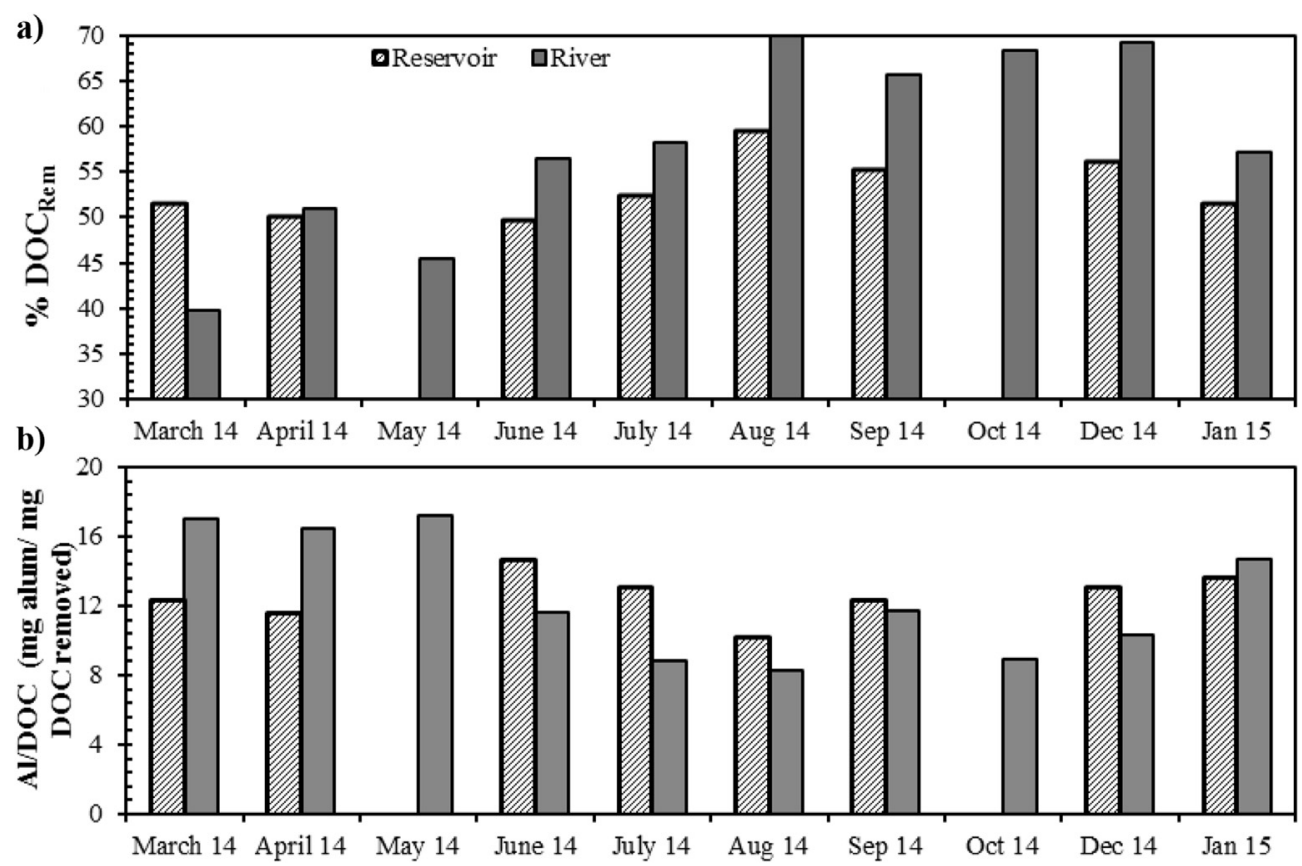

Fig. 3. Average data of (a) $\% \mathrm{DOC}_{\mathrm{Rem}}$ and (b) $\mathrm{Al} / \mathrm{DOC}$ from jar tests of river and reservoir waters. 
with organics collected during dry seasons (Figs. 1 and 2, S1 and S2).

In contrast, water samples collected from the reservoir during wet seasons had similar \%DOC removals and $\mathrm{Al} / \mathrm{DOC}$ values compared to that collected during dry seasons (\%DOC Rem $_{1}: 54 \pm 4 \%$ for wet seasons vs $52 \pm 2 \%$ for dry seasons; Al/DOC: $13 \pm 2 \mathrm{mg} / \mathrm{mg}$ DOC for wet seasons vs $13 \pm 0.8 \mathrm{mg} / \mathrm{mg}$ DOC for dry seasons). Coefficient of variation values of reservoir waters collected during the wet and dry seasons were $1.9 \%$ and $0.1 \%$ for $\% \mathrm{DOC}_{\text {Rem }}$ and $\mathrm{Al} / \mathrm{DOC}$ respectively. For river waters, the lowest alum dose rates $(7.7 \mathrm{Al} /$ DOC) was for water collected at end of June (the start of catchment runoff, Supplementary data, Fig. S4). For reservoir waters, the lowest alum dose rate (10 $\mathrm{Al} / \mathrm{DOC})$ with the highest DOM removal ratio $(59.4 \%)$ was for water collected at end of the winter season, coinciding to the higher relative abundance of organics of high MW-humic compounds (Figs. 2 and S2). Sachse et al. (2005) reported that as a result of low temperature, autochthonous precursor activities are reduced in winter and DOM is mainly from allochthonous inputs. The latter is likely to be more amenable to removal by coagulation (Fabris et al., 2008).

\subsection{Characterization of DOM in alum treated waters}

SUVA and SpCol values of ED alum treated waters are shown in Table 1. Alum treated waters had lower SUVA and SpCol values than raw waters, as expected. This is attributed to the greater effectiveness of coagulation in removal of aromatic and hydrophobic compounds, as reported by Ødegaard et al. (2010) and others. For river waters, those collected during wet seasons had higher residual aromatic constituents after ED [SUVA: $2.0 \pm 0.2 \mathrm{~L} /(\mathrm{mg} \mathrm{m})$; SpCol: $2.5 \pm 0.5 \mathrm{HU} \mathrm{L} / \mathrm{mg}$ ] compared with residual organics in waters collected during the dry seasons [SUVA: $1.5 \pm 0.3 \mathrm{~L} /(\mathrm{mg} \mathrm{m})$; SpCol: $1.3 \pm 0.2 \mathrm{HU} \mathrm{L} / \mathrm{mg}$ ]. In contrast, for reservoir waters, there were no differences in the SUVA and SpCol levels of treated waters for waters collected during various seasons [SUVA: $1.8 \pm 0.1 \mathrm{~L} /(\mathrm{mg}$ $\mathrm{m})$ for the dry season and $1.8 \pm 0.1 \mathrm{~L} /(\mathrm{mg} \mathrm{m})$ for wet season; SpCol: $1.2 \pm 0.3 \mathrm{HU} \mathrm{L} / \mathrm{mg}$ for dry season and $1.5 \pm 0.4 \mathrm{HU} \mathrm{L} / \mathrm{mg}$ for wet season].

For river waters, there were no differences in the mean AMW of treated waters for raw waters collected during the wet and dry seasons $(784 \pm 76$ Da for wet season and $800 \pm 29$ Da for dry season). However, the mean AMW-humic component was found to be higher in waters collected during wet seasons compared with the dry season $(705 \pm 33$ Da vs $640 \pm 40 \mathrm{Da})$. For reservoir waters, there were no differences in the AMW and AMW-humic levels of treated waters [AMW: $848 \pm 13$ Da for wet season samples and $817 \pm 50$ Da for dry season; AMW-humic: $698 \pm 9$ Da for the wet season and $691 \pm 6$ Da for dry season].

Table 1

DOM concentration and character for ED alum treated waters from river and reservoir.

\begin{tabular}{|c|c|c|c|c|c|c|}
\hline & \multicolumn{2}{|c|}{$\begin{array}{l}\text { DOC Residual } \\
(\mathrm{mg} / \mathrm{L})\end{array}$} & \multicolumn{2}{|l|}{$\begin{array}{l}\text { SUVA } \\
{[\mathrm{L} /(\mathrm{mg} \mathrm{m})]}\end{array}$} & \multicolumn{2}{|l|}{$\begin{array}{l}\text { SpCol } \\
\text { (HU L/mg) }\end{array}$} \\
\hline & Reservoir & River & Reservoir & River & Reservoir & River \\
\hline Mar. 14 & 7.65 & 8.91 & 1.97 & 1.69 & 1.19 & NA \\
\hline April 14 & 8.70 & 6.14 & 1.75 & 1.67 & 1.19 & 1.22 \\
\hline May 14 & NA & 6.99 & NA & 1.13 & NA & 1.09 \\
\hline June 14 & 6.92 & 7.42 & 1.66 & 1.91 & 1.29 & 1.93 \\
\hline July 14 & 6.94 & 10.62 & 1.94 & 2.30 & 2.03 & 2.44 \\
\hline Aug 14 & 6.68 & 5.71 & 1.87 & 1.96 & 1.03 & 2.34 \\
\hline Sep 14 & 6.62 & 4.89 & 1.89 & 1.88 & 1.51 & 2.22 \\
\hline Oct 14 & NA & 5.20 & NA & 1.75 & NA & 3.42 \\
\hline Dec 14 & 6.01 & 4.30 & 1.66 & 1.36 & 1.00 & 1.25 \\
\hline Jan 15 & 6.90 & 5.08 & 1.72 & 1.79 & 1.30 & 1.54 \\
\hline
\end{tabular}

From the resolved peaks of organics in waters before and after alum treatment (at ED), the percentage removals of each peak were determined, shown in Fig. 4a. High molecular weight (HMW) peaks, P1:P5 (MW > $1750 \mathrm{Da}$ ) identified by HPSEC-UV detection can generally be easily removed by coagulant treatment (Allpike et al., 2005; Chow et al., 2008; Soh et al., 2008; Wang et al., 2010). These peaks ( $\mathrm{MW}>1750 \mathrm{Da}$ ) present in waters collected during different seasons were completely removed from waters by alum treatment.

The percentage removals of compounds of LMW (peaks of $\mathrm{MW}<1 \mathrm{KDa}$ ) in river waters $(33 \pm 14 \%)$ were similar to removals of compounds in reservoir waters $(30 \pm 7 \%)$, Fig. $4 a$. The percentage mean reduction of P6 (1250 Da) was higher for river waters compared to reservoir waters $(75 \pm 9 \%$ for river vs $66 \pm 8 \%$ for reservoir). Samples collected during dry and wet seasons of surface waters (reservoir or river had similar percentage removals of P6 (reservoir: $65 \pm 10 \%$ for dry season vs $67 \pm 7 \%$ for wet season; river $75 \pm 8 \%$ for dry season vs $75 \pm 9 \%$ for wet season). Samples collected during the dry seasons had lower removals of compounds of LMW peaks (MW < $1 \mathrm{KDa}$ ) compared with samples collected during wet season (reservoir: $24 \pm 1 \%$ for dry season vs $35 \pm 6 \%$ for wet season; river: $22 \pm 12 \%$ for dry season vs $41 \pm 9 \%$ for wet season).

The percentage removals of resolved peaks with alum treatment at ED determined by HPSEC-fluorescence detection are shown in Fig. 4b. HMW humic-like compounds (P1:P2; MW > $1200 \mathrm{Da}$ ) were easily removed from waters collected during the various seasons. Removals of LMW humic-like compounds (P4:P6; MW < 1000 Da) by coagulation from surface waters collected during the wet season were similar to that of waters collected during the dry season (reservoir: $36 \pm 8 \%$ for dry season vs $35 \pm 1 \%$ for wet season; river $34 \pm 9 \%$ for dry season vs $34 \pm 10 \%$ for wet season). In contrast, samples collected during dry season had higher removals of P3 (1175 Da) compound(s) compared with samples collected during wet season for both river and reservoir waters (reservoir: $71 \pm 10 \%$ for dry season vs $62 \pm 1 \%$ for wet season; river: $86 \pm 3 \%$ for dry season vs $72 \pm 9 \%$ for wet season). These results are consistent with findings from the study of Aslam et al. (2013), who reported that most low molecular weight humic-like compounds are recalcitrant to treatment by alum and remain in treated water.

\subsection{Trihalomethane formation potential for treated waters}

Total THMFP and constituent THM compounds for river and reservoir waters after ED alum treatment are shown in Fig. 5. Average total THMFP for alum treated waters sourced from the river $(\overline{\mathrm{X}} \pm \mathrm{SD}: 202 \pm 26 \mu \mathrm{g} / \mathrm{L})$ was similar to treated waters sourced from the reservoir $(\bar{X} \pm S D: 209 \pm 8 \mu \mathrm{g} / \mathrm{L})$. Average specific THMFP values (the ratio of THMFP to DOC concentration) for treated river waters $(32 \pm 5 \mu \mathrm{g} / \mathrm{mg}$ DOC) was also similar to that for treated reservoir waters (30 $\pm 2 \mu \mathrm{g} / \mathrm{mg}$ DOC). Further, no apparent difference was found in the percentages of chlorinated compounds (e.g., \% $\mathrm{CHCl}_{3}$ ) between treated river and reservoir waters $\left(\% \mathrm{CHCl}_{3}: 36 \pm 8 \%\right.$ for river waters vs $35 \pm 2 \%$ for reservoir waters).

Treated waters of those sourced from the river collected during dry seasons had residual DOM of lower THMFP $(172 \pm 2 \mu \mathrm{g} / \mathrm{L})$ than organics of waters collected during wet seasons $(217 \pm 18 \mu \mathrm{g} / \mathrm{L})$. However no apparent difference was found in the mean specific THMFP values ( $31 \pm 3 \mu \mathrm{g} / \mathrm{mg}$ DOC for dry seasons vs $32 \pm 6 \mu \mathrm{g} / \mathrm{mg}$ DOC for wet seasons). These findings indicate that residual DOC concentration is a key factor that determines THM formation levels in treated waters. Residual DOC concentrations in waters collected during dry and wet seasons were $5.6 \pm 0.5 \mathrm{mg} / \mathrm{L}$ and $7.2 \pm 2.0 \mathrm{mg} / \mathrm{L}$ respectively.

The relative abundances of THM chlorinated species were different between waters collected during dry and wet seasons 

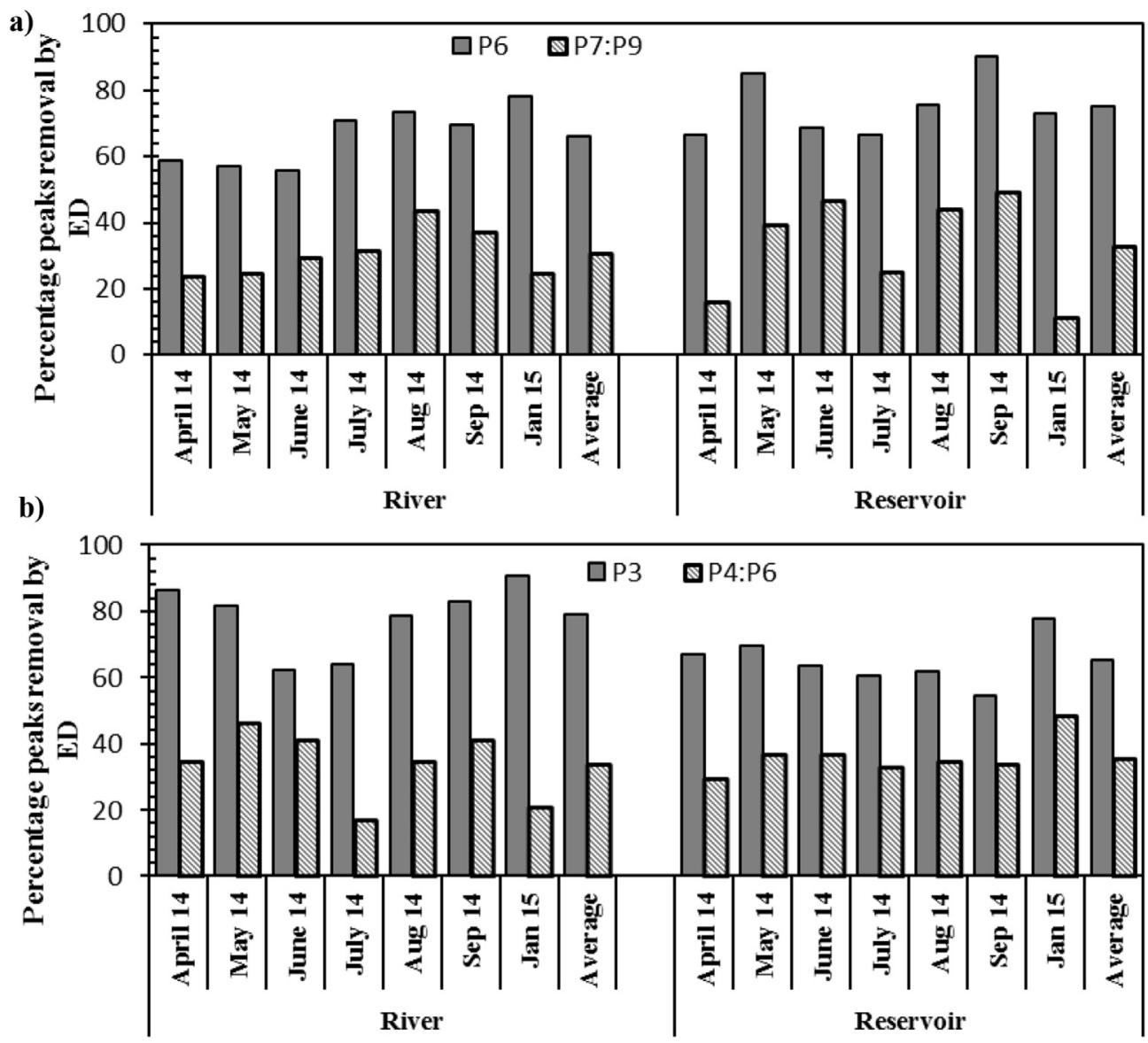

Fig. 4. Percentage removals of resolved peaks determined by HPSEC with UV-detection (a) and with fluorescence-detection (b).

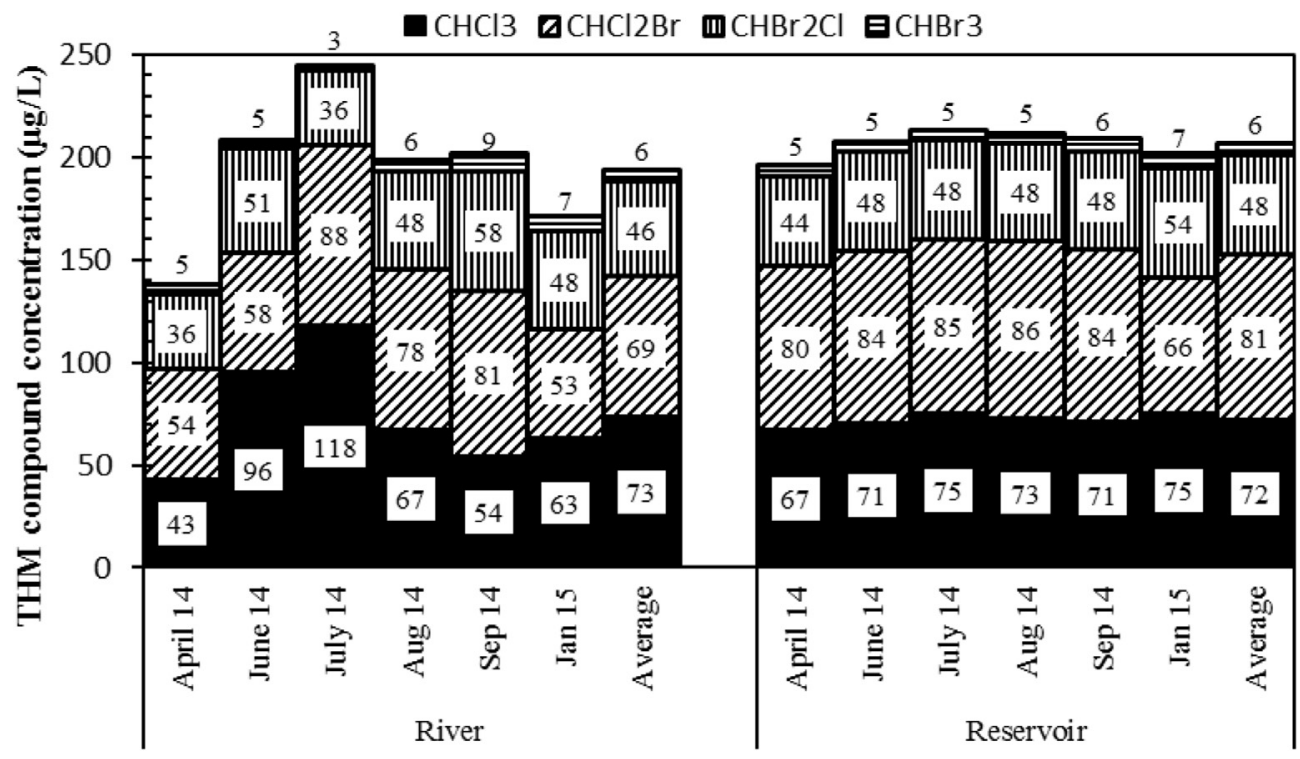

Fig. 5. Average constituent THM compounds $(\mu \mathrm{g} / \mathrm{L})$ for ED alum treated waters from river and reservoir waters.

with slightly lower potentials in samples collected in the dry seasons than wet seasons (e.g., \% $\mathrm{CHCl}_{3}$ : $31 \pm 6 \%$ for dry seasons vs 38 $\pm 8 \%$ for wet seasons). However for treated waters from the reservoir, no significant differences were found between waters collected during dry and wet seasons for total THMFP concentration $(212 \pm 10 \mu \mathrm{g} / \mathrm{L}$ for dry seasons vs $208 \pm 7 \mu \mathrm{g} / \mathrm{L}$ for wet seasons) and the relative abundances of THM chlorinated species (e.g., \% $\mathrm{CHCl}_{3}$ : $34 \pm 4 \%$ for dry seasons vs $35 \pm 1 \%$ for wet seasons) as shown in Fig. 5. However, Specific THMFPs were found to be slightly higher in reservoir treated waters collected during wet season 
compared with the dry season $(30 \pm 1 \mu \mathrm{g} / \mathrm{mg}$ DOC vs $27 \pm 2 \mu \mathrm{g} / \mathrm{mg}$ $\mathrm{DOC})$.

From studies conducted to determine the impacts of catchment characteristics on the quality of waters used for domestic supply, we previously reported the influence of the vegetation (native, pine, grasslands) and soil texture (sandy/clayey) on the characters and concentrations of DOMs present in surface and sub-surface runoff waters collected from various zero-order catchments (ZOCs), Myponga Reservoir-catchment (Awad et al., 2015). The DOC concentration, DOM character by UV-absorbance and HPSEC of subsurface $(\sim 30 \mathrm{~cm})$ water samples collected over two seasons (winter and spring) of 2014 are presented in Figs. S3 and S4 (Supplementary data). In summer-autumn seasons, runoff and subsurface water flows were not found to occur in any of the ZOCs. At the start of the wet seasons, DOC concentrations and the relative abundances of coagulable organics (aromatic and high MW peaks organic compounds) were found to be much higher than at the end of the wet season (these features decreased with time, Figs. S4 and S5). The highest concentration of DOC released into subsurface waters and lateral flows occurred after the first major rainfall event, as similarly reported by Chow et al. (2011).

Compared to ZOC waters, river waters showed the same trend, with the highest organic concentration (Fig. 1b) occurring at the end of June and in July (the start of catchment runoff, Figs. S3 and S4). Evans et al. (2005) and Ritson et al. (2014) reported an increase in DOM concentrations in stream waters during storm events as a result of flushing of the upper organic soil horizons. Further, the highest relative abundances of coagulable organics (aromatic and high MW peaks organic compounds) also occurred at the end of June and in July. These features (concentration and character of DOM) led to a higher percentage removal of organics by coagulation and using a lower alum dose rate (Fig. 3). However, these features led to an increase in the total THM formation potential (Fig. 5). These results indicate that DOM present in river waters and their treatability by alum are highly impacted by catchment runoff and by seasonal variation.

In contrast, for reservoir waters, no apparent differences were found in the DOC concentrations between samples collected during the wet and dry seasons (Fig. 1c). Further, aromatic compounds and MW distributions in reservoir waters (Figs. 1e and 2) appeared to be more constant during the collection period compared with river waters (Figs. 1d and 2). Wei et al. (2008) reported that SUVA levels of reservoir waters (East-Lake, China) collected during different seasons had similar values. However, Wei et al. (2008) also reported differences in the MW distributions during the collection period. In our research, similarity in these features (concentration and character of DOM) led to consequently similar percentage removals of organics by alum, similar alum dose rates (Fig. 3) and THMFP (Fig. 5) between samples collected during the dry and the wet seasons. This may be attributed to storage of larger water volumes within the reservoir enabling mixing of influent waters and stabilization of water quality.

\section{Conclusions}

Catchment runoff and flow patterns combine to have a significant effect on the concentration and character of organics in river waters. DOC concentration and relative abundance of coagulable organics were highest in the waters collected during the first flush from the ZOCs studied and consequently in the river water. Waters collected during wet season have higher DOC concentrations, higher relative abundance of aromatic, HMW and humic-like compounds than waters collected during dry season. Consequently, river waters collected during wet season were found to have higher THMFP formation, and higher percentage removal of organics by coagulation and at a lower alum dose rate compared with waters collected during dry seasons.

Storage of large volumes of water in the reservoir enables mixing of influent waters and stabilization of water quality. This resulted in no measurable differences in the reservoir output water quality (at the water treatment plant) between the dry and wet seasons. DOM in reservoir waters and its treatability were found to be less seasonally variable compared with river waters.

\section{Acknowledgements}

The authors gratefully acknowledge the financial support provided by the Australian Research Council under Grant LP110200208, SA Water and the SA Department for Environment, Water and Natural Resources and the Goyder Institute for Water Research. The authors thank Mr Jonathan Cohen for his valuable support in field work.

\section{Appendix A. Supplementary data}

Supplementary data related to this article can be found at http:// dx.doi.org/10.1016/j.envpol.2016.10.054.

\section{References}

Agency, U.S.E.P., 2012. 2012 Edition of the Drinking Water Standards and Health Advisories. Washington, DC.

Allard, S., Tan, J., Joll, C.A., von Gunten, U., 2015. Mechanistic study on the formation of $\mathrm{Cl}$-/Br-/I-Trihalomethanes during chlorination/chloramination combined with a theoretical cytotoxicity evaluation. Environ. Sci. Technol. 49, 11105-11114.

Allpike, B.P., Heitz, A., Joll, C.A., Kagi, R.I., Abbt-Braun, G., Frimmel, F.H., Brinkmann, T., Her, N., Amy, G., 2005. Size exclusion chromatography to characterize DOC removal in drinking water treatment. Environ. Sci. Technol. 39, 2334-2342.

Aslam, Z., Chow, C.W., Murshed, F., van Leeuwen, J.A., Drikas, M., Wang, D., 2013. Variation in character and treatability of organics in river water: an assessment by HPAC and alum coagulation. Sep. Purif. Technol. 120, 162-171.

Awad, J., van Leeuwen, J., Abate, D., Pichler, M., Bestland, E., Chittleborough, D.J. Fleming, N., Cohen, J., Liffner, J., Drikas, M., 2015. The effect of vegetation and soil texture on the nature of organics in runoff from a catchment supplying water for domestic consumption. Sci. Total Environ. 529, 72-81.

Beale, E.M.L., 1962. Some uses of computers in operational research. Ind. Organ. 31 $51-52$.

Billett, M.F., Deacon, C.M., Palmer, S.M., Dawson, J.J.C., Hope, D., 2006. Connecting organic carbon in stream water and soils in a peatland catchment. J. Geophys. Res. Biogeosciences 111, G02010.

Carstea, E.M., Baker, A., Pavelescu, G., Boomer, I., 2009. Continuous fluorescence assessment of organic matter variability on the Bournbrook River, Birmingham, UK. Hydrol. Process. 23, 1937-1946.

Carter, R., Linge, K., Heitz, A., Liew, D., Allard, S., Joll, C., 2015. Disinfection byproducts: not just an issue for drinking water, but also potentially for swimming pool waters. J. Aust. Water Assoc. 42, 82-87.

Chen, M., He, W., Choi, I., Hur, J., 2015. Tracking the monthly changes of dissolved organic matter composition in a newly constructed reservoir and its tributaries during the initial impounding period. Environ. Sci. Pollut. Res. 23, 1274-1283.

Chen, W., Westerhoff, P., Leenheer, J.A., Booksh, K., 2003. Fluorescence excitation-emission matrix regional integration to quantify spectra for dissolved organic matter. Environ. Sci. Technol. 37, 5701-5710.

Chow, A.T., O'Geen, A.T., Dahlgren, R.A., Díaz, F.J., Wong, K.-H., Wong, P.-K., 2011. Reactivity of litter leachates from California Oak Woodlands in the formation of disinfection by-products. J. Environ. Qual. 40, 1607-1616.

Chow, C.W.K., Fabris, R., Leeuwen, J.v., Wang, D., Drikas, M., 2008. Assessing natural organic matter treatability using high performance size exclusion chromatography. Environ. Sci. Technol. 42, 6683-6689.

Chow, C.W.K., Leeuwen, J.A.v., Drikas, M., Fabris, R., Spark, K.M., Page, D.W., 1999. The impact of the character of natural organic matter in conventional treatment with alum. Water Sci. Technol. 40, 97-104.

Chow, C.W.K., van Leeuwen, J.A., Fabris, R., Drikas, M., 2009. Optimised coagulation using aluminium sulfate for the removal of dissolved organic carbon. Desalination 245, 120-134.

Chu, W.-H., Gao, N.-Y., Deng, Y., Krasner, S.W., 2010. Precursors of dichloroacetamide, an emerging nitrogenous DBP formed during chlorination or chloramination. Environ. Sci. Technol. 44, 3908-3912.

Edzwald, J.K., Tobiason, J.E., 1999. Enhanced coagulation: US requirements and a broader view. Water Sci. Technol. 40, 63-70.

Evans, C.D., Monteith, D.T., Cooper, D.M., 2005. Long-term increases in surface water 
dissolved organic carbon: observations, possible causes and environmental impacts. Environ. Pollut. 137, 55-71.

Fabris, R., Chow, C.W.K., Drikas, M., Eikebrokk, B., 2008. Comparison of NOM character in selected Australian and Norwegian drinking waters. Water Res. 42, 4188-4196.

Goslan, E.H., Fearing, D.A., Banks, J., Wilson, D., Hills, P., Campbell, A.T., Parsons, S.A., 2002. Seasonal variations in the disinfection by-product precursor profile of a reservoir water. J. Water Supply Res. Technol. - Aqua 51, 475-482.

King, W.D., Dodds, L., Allen, A.C., 2000a. Relation between stillbirth and specific chlorination by-products in public water supplies. Environ. Health Perspect. 108, 883-886.

King, W.D., Marrett, L.D., Woolcott, C.G., 2000b. Case-control study of colon and rectal cancers and chlorination by-products in treated water. Cancer Epidemiol. Biomarkers Prev. 9, 813-818.

Korshin, G., Chow, C.W.K., Fabris, R., Drikas, M., 2009. Absorbance spectroscopybased examination of effects of coagulation on the reactivity of fractions of natural organic matter with varying apparent molecular weights. Water Res. 43, 1541-1548.

Lumsdon, D.G., Stutter, M.I., Cooper, R.J., Manson, J.R., 2005. Model assessment of biogeochemical controls on dissolved organic carbon partitioning in an acid organic soil. Environ. Sci. Technol. 39, 8057-8063.

Matilainen, A., Vepsäläinen, M., Sillanpää, M., 2010. Natural organic matter removal by coagulation during drinking water treatment: a review. Adv. Colloid Interface Sci. 159, 189-197.

Mattsson, T., Kortelainen, P., Laubel, A., Evans, D., Pujo-Pay, M., Räike, A., Conan, P., 2009. Export of dissolved organic matter in relation to land use along a European climatic gradient. Sci. Total Environ. 407, 1967-1976.

Min, J.-Y., Min, K.-B., 2016. Blood trihalomethane levels and the risk of total cancer mortality in US adults. Environ. Pollut. 212, 90-96.

Ng, M., Liu, S., Chow, C.W.K., Drikas, M., Amal, R., Lim, M., 2013. Understanding effects of water characteristics on natural organic matter treatability by PACl and a novel PACl-chitosan coagulants. J. Hazard. Mater. 263, 718-725. Part 2.

Ødegaard, H., Østerhus, S., Melin, E., Eikebrokk, B., 2010. NOM removal technologies - norwegian experiences. Drink. Water Eng. Sci. 3, 1-9.

Quilbé, R., Rousseau, A.N., Duchemin, M., Poulin, A., Gangbazo, G., Villeneuve, J.-P., 2006. Selecting a calculation method to estimate sediment and nutrient loads in streams: application to the Beaurivage River (Québec, Canada). J. hydrology 326, 295-310.

Ran, L., Lu, X.X., Sun, H., Han, J., Li, R., Zhang, J., 2013. Spatial and seasonal variability of organic carbon transport in the Yellow River, China. J. hydrology 498, 76-88.

Rice, E.W. Bridgewater, L., American Public Health, A. American Water Works, A. 2012. Standard Methods for the Examination of Water and Wastewater. American Public Health Association, Washington, D.C.

Richardson, S., 2005. New disinfection by-product issues: emerging DBPs and alternative routes of exposure. Glob. Nest J. 7, 43-60.

Richardson, S., Postigo, C., 2012. Drinking water disinfection by-products. In: Barceló, D. (Ed.), Emerging Organic Contaminants and Human Health. Springer, Berlin Heidelberg, pp. 93-137.

Richardson, S.D., Plewa, M.J., Wagner, E.D., Schoeny, R., DeMarini, D.M., 2007.
Occurrence, genotoxicity, and carcinogenicity of regulated and emerging disinfection by-products in drinking water: a review and roadmap for research. Mutat. Research/Reviews Mutat. Res. 636, 178-242.

Ritson, J.P., Graham, N.J.D., Templeton, M.R., Clark, J.M., Gough, R., Freeman, C., 2014 The impact of climate change on the treatability of dissolved organic matter (DOM) in upland water supplies: a UK perspective. Sci. Total Environ. 473-474, 714-730.

Sachse, A., Henrion, R., Gelbrecht, J., Steinberg, C.E.W., 2005. Classification of dissolved organic carbon (DOC) in river systems: influence of catchment characteristics and autochthonous processes. Org. Geochem. 36, 923-935.

Siddique, A., Saied, S., Mumtaz, M., Hussain, M.M., Khwaja, H.A., 2015. Multipathways human health risk assessment of trihalomethane exposure through drinking water. Ecotoxicol. Environ. Saf. 116, 129-136.

Soh, Y.C., Roddick, F., Van Leeuwen, J., 2008. The impact of alum coagulation on the character, biodegradability and disinfection by-product formation potential of reservoir natural organice matter $(\mathrm{NOM})$ fractions. Water Sci. Technol. 58, $1173-1179$.

Stutter, M.I., Dunn, S.M., Lumsdon, D.G., 2012. Dissolved organic carbon dynamics in a UK podzolic moorland catchment: linking storm hydrochemistry, flow path analysis and sorption experiments. Biogeosciences 9, 2159-2175.

van Leeuwen, J., Daly, R., Holmes, M., 2005. Modeling the treatment of drinking water to maximize dissolved organic matter removal and minimize disinfection by-product formation. Desalination 176, 81-89.

van Leeuwen, J., Holmes, M., Kaeding, U., Daly, R., Bursill, D., 2009. Development and implementation of the software mEnCo to predict coagulant doses for DOC removal at full-scale WTPs in South Australia. J. Water Supply Res. TechnologyAQUA 58, 291-298.

Villanueva, C.M., Cantor, K.P., Grimalt, J.O., Malats, N., Silverman, D., Tardon, A. Garcia-Closas, R., Serra, C., Carrato, A., Castaño-Vinyals, G., Marcos, R. Rothman, N., Real, F.X., Dosemeci, M., Kogevinas, M., 2007. Bladder cancer and exposure to water disinfection by-products through ingestion, bathing, showering, and swimming in pools. Am. J. Epidemiol. 165, 148-156.

Wang, D., Xing, L., Xie, J., Chow, C.W.K., Xu, Z., Zhao, Y., Drikas, M., 2010. Application of advanced characterization techniques to assess DOM treatability of micropolluted and un-polluted drinking source waters in China. Chemosphere 81, 39-45.

Wei, Q.-S., Feng, C.-h., Wang, D.-S., Shi, B.-y., Zhang, L.-t., Wei, Q., Tang, H.-X., 2008 Seasonal variations of chemical and physical characteristics of dissolved organic matter and trihalomethane precursors in a reservoir: a case study. J. Hazard. Mater. 150, 257-264

Weishaar, J.L., Aiken, G.R., Bergamaschi, B.A., Fram, M.S., Fujii, R., Mopper, K., 2003. Evaluation of specific ultraviolet absorbance as an indicator of the chemical composition and reactivity of dissolved organic carbon. Environ. Sci. Technol. 37, 4702-4708.

White, M.C., Thompson, J.D., Harrington, G.W., Singer, P.C., 1997. Evaluating criteria for enhanced coagulation compliance. J. Am. Water Works Assoc. 89, 64-77.

Zepp, R.G., Erickson Iii, D.J., Paul, N.D., Sulzberger, B., 2007. Interactive effects of solar UV radiation and climate change on biogeochemical cycling. Photochem. Photobiological Sci. 6, 286-300. 